\title{
Experimental Investigation on the Compressive Strength and Durability Performance of Modified Dry-Stack Hollow Sandcrete Blocks
}

\author{
Fredrick Onyancha Arasa ${ }^{1,2}$, Richard Onchiri ${ }^{3}$, Zachary C. Abiero-Gariy ${ }^{4}$ \\ ${ }^{1}$ Department of Civil Engineering, Pan African University for Basic Sciences, Technology and Innovation (PAUSTI), Nairobi, \\ Kenya \\ ${ }^{2}$ Department of Civil and Structural Engineering Masinde Muliro University of Science and Technology, Kakamega, Kenya \\ ${ }^{3}$ Department of Building and Civil Engineering, Technical University of Mombasa, Mombasa, Kenya \\ ${ }^{4}$ Department of Civil Construction and Environmental Engineering, Jomo Kenyatta University of Agriculture and Technology \\ (JKUAT), Nairobi, Kenya \\ Email: eng.arasa@gmail.com
}

How to cite this paper: Arasa, F.O., Onchiri, R. and Abiero-Gariy, Z.C. (2021) Experimental Investigation on the Compressive Strength and Durability Performance of Modified Dry-Stack Hollow Sandcrete Blocks. Open Access Library Journal, 8: e8216.

https://doi.org/10.4236/oalib.1108216

Received: November 23, 2021

Accepted: December 11, 2021

Published: December 14, 2021

Copyright $\odot 2021$ by author(s) and Open Access Library Inc.

This work is licensed under the Creative Commons Attribution International License (CC BY 4.0).

http://creativecommons.org/licenses/by/4.0/ (c) (i) Open Access

\begin{abstract}
The increase in construction costs has resulted in the shortage of decent housing in Kenya. As a result, the majority of the population lives in substandard housing. One way of reducing the cost of housing is by replacing the mortared masonry units with dry-stack hollow masonry units. In this study, Dry-stack hollow Sandcrete Blocks (DHSBs) were developed by utilizing blended sand (30\% marine and 70\% lateritic sand) and sugarcane bagasse ash (SCBA) (15\%) as replacement of river sand and partial replacement of Ordinary Portland Cement, respectively. Two types of dry-stack hollow sandcrete blocks (DHSBs) were mechanically developed and identified as T-DHSBs and R-DHSBs. The compressive strength and durability performance of the DHSBs were investigated through laboratory experiments. The durability of the DHSBs was assessed through water absorption and abrasion tests. The 28-day compressive strengths of T-DHSBs and R-DHSBs were found to be $3.58 \mathrm{Mpa}$ and 4.04 Mpa respectively and the water absorption values for T-DHSBs and R-DHSBs were $8.98 \%$ and $9.39 \%$ respectively. The losses of weight due to abrasion for T-DHSB and R-DHSBs were $0.056 \%$ and $0.051 \%$ respectively. The compressive strength and durability of the DHSBs were found to meet the specifications provided in NIS 87:2000 and BS 5628-1:2005 respectively.
\end{abstract}

\section{Subject Areas}

Building Blocks 


\section{Keywords}

Blended Sand, Dry-Stack Hollow, Sandcrete Blocks, Compressive Strengths, Abrasion, Water Absorption

\section{Introduction}

Interlocking blocks are sometimes referred to as mortar less or "dry-stack" masonry construction. In this technique, masonry units are laid without mortar; however, a limited amount of mortar is used for starter and top courses. DHSBs combines the advantages of hollow and interlocking masonry systems: the system eliminates the use of conventional cement mortar bonding ensuring faster building; The blocks can be laid by unskilled workers; they are also ideal for situations where the builder wants to conform to "green" requirements; the manufacturer requires no power, minimal transport and makes little mess [1]. Highly hollow concrete masonry units are advantageous because of the rapid execution of work, reduction in construction cost, better insulation and thermal properties, more durable, good bonding of mortar and plaster, construction of reinforced and prestressed masonry among other advantages [2] [3].

The materials that are commonly used in the making of interlocking blocks include: soil-cement, sand-cement and concrete. Some examples of interlocking blocks include: Haener Block, Azar Block, Sparlock, Durisol, Faswall and Endura Blocks [1]. Hyraform interlocking blocks are gaining popularity Kenya, Nigeria, Zambia and South Africa [4] [5].

The compressive strength of a masonry unit is largely used to describe several design properties of the masonry wall. Compressive testing on unit blocks is important for both quality control and design. Recent studies have revealed that the use of nonconventional materials produces cheap interlocking blocks which meet the minimum compressive strength requirements. Sornchomkeaw and Duangkeaw [6] recommended a cement to sand ratio of 1:6 with $5 \%$ of bottom ash. Vennila et al. [7] reported that waste broken tiles and Acacia nilotica ash from the burning of karuvelammaram produces low-cost concrete thus reducing cement use and the emission of greenhouse gas into the atmosphere.

Ahmad's [8] study revealed that the compressive strength property of interlocking masonry units/blocks is $20 \%$ and $40 \%$ higher than concrete masonry hollow blocks and bricks respectively. Moreover, Assiamah et al.'s [9] comparative study of interlocking and sandcrete blocks for building walling systems revealed no statistical difference between the compressive strength of interlocking blocks and conventional sandcrete blocks. They however noted that the construction cost and speed of construction of the two systems of construction varied significantly.

In order to encourage the use of dry-stack technology, researchers need to develop high-quality interlocking blocks at a minimal cost. Ombiro and Mbugua 
[5] attributed the use of interlocking red bricks in housing projects is to the availability of construction technology, cost of construction, access to construction, equipment by individuals, and quality of building blocks and training.

Limited design guidelines on dry-stack hollow sandcrete systems underscore the need for extensive experimental studies for data provision in design, quality control and encouragement of its use. In this study, dry-stack hollow sandcrete block DHSBs $(450 \times 225 \times 225 \mathrm{~mm}$ produced from the optimum mix of Cement/SCBA: Marine/lateritic of ratio $1(0.85 / 0.15)$ to $6(0.30 / 0.70)$ and 0.5 water-cement ratio is used [10]. The compressive strength and durability performance of the DHSBs has been investigated in view of encouraging its use.

\section{Materials and Methods}

\subsection{Materials}

The constituent materials used for the production of T-DHSBs and R-DHSBs were: Cement, Sugarcane bagasse ash (SCBA), lateritic sand, marine sand, and portable water. The materials were sourced from various parts of Kenya.

\section{Cement and Sugarcane Bagasse Ash}

In the study, Ordinary Portland Cement (OPC $42.5 \mathrm{~N}$ ) conforming to the requirements KS EAS 18-1:2001 [11] was used. It was obtained from a retail shop in Central Kenya. Sugarcane Bagasse Ash (SCBA) was obtained from Kabras Sugar Company in western Kenya. It was dried and sieved through a $300 \mu \mathrm{mm}$ sieve and then packed into polythene bags so as to maintain moisture (see Plate $1(\mathrm{a}))$.

\section{Lateritic and marine sand}

Lateritic sand was obtained in depths of $1.5 \mathrm{~m}$ to $2.0 \mathrm{~m}$ using the method of disturbed sampling. It was prepared by washing, drying and sieving so as to remove excess clay, silt, debris, and organic content so as to fulfill the requirements of conventional sand provided in BS 882:1992 [12] (see Plate 1(b) and Plate $1(\mathrm{c})$ ). The hygroscopic characteristic of clay weakens the bond between the aggregate particles and the cement paste resulting in a lower compressive strength [13]. Marine sand samples were obtained from the offshore strip in Mombasa Kenya. Lateritic sand and marine sand (blended sand) used in this study passed through $4.75 \mathrm{~mm}$ British standard sieve and retained on sieve 150 $\mu \mathrm{m}$.

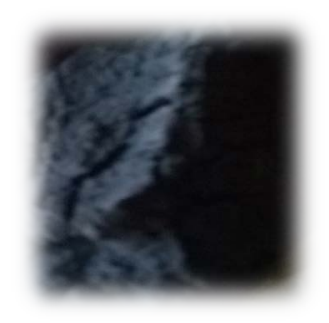

(a)

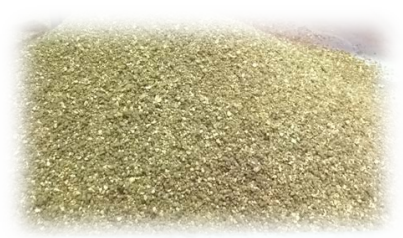

(b)

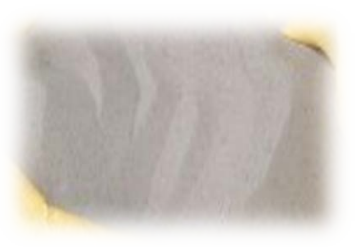

(c)

Plate 1. (a) Sugarcane bagasse ash; (b) Lateritic sand; (c) Marine sand samples. 


\section{Water}

Tap water used in this study conformed in totality to the specifications in BS 3148:1980 [14].

\section{Materials testing and properties}

The test procedure for blended sand and Ordinary Portland cement were conducted as per BS 882:1992 [12] and KS EAS 18-1:2001 [11] respectively. The properties of the materials used in this study are presented in Tables 1-4 [10]. Figure 1 presents the grading of the optimum blended sand used in this study.

\subsection{Mix Proportions}

The mix proportion used in the study was developed through preliminary tests done on conventional $450 \times 225 \times 225 \mathrm{~mm}$ hollow sandcrete blocks produced using the non-conventional materials at SSD conditions. The tests had established that the optimum ratio of Cement/SCBA to Marine/lateritic was 1 $(0.85 / 0.15)$ to $6(0.3 / 0.7)$ at 0.5 water-cement ratio Arasa et al. [10]. Table 5 shows the mix proportions used in this study.

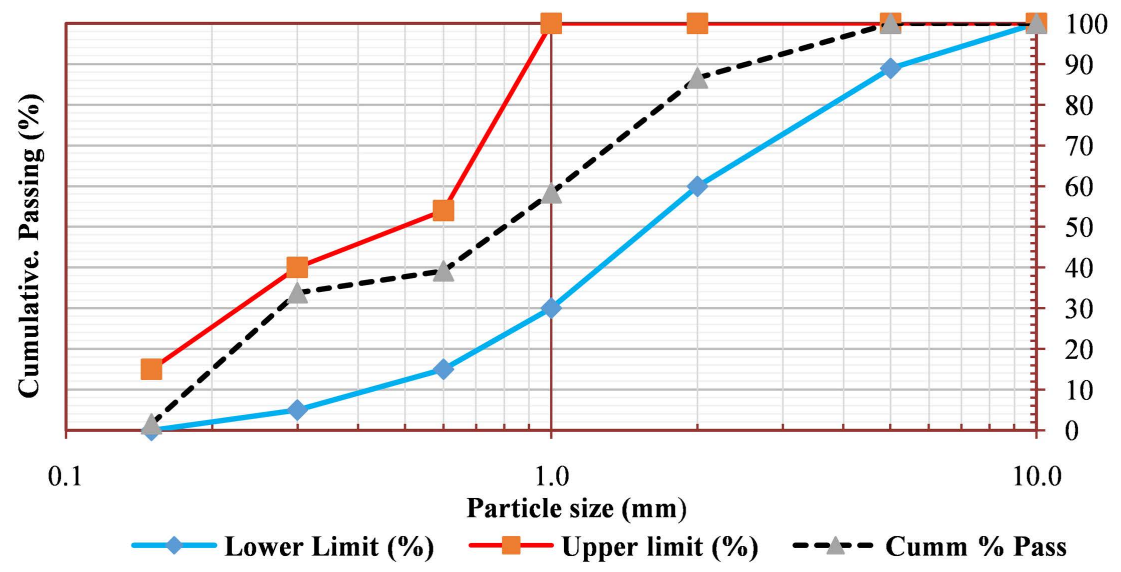

Figure 1. Sieve analysis results for blended sand (30:70 marine sand to lateritic sand mix)

Table 1. Physical properties of lateritic sand.

\begin{tabular}{cc}
\hline PROPERTY & TEST RESULT \\
\hline Specific gravity (SSD) & 2.8 \\
Fineness modulus & 3.5 \\
Bulk density; & \\
Loose & $1519 \mathrm{Kg} / \mathrm{m}^{3}$ \\
Compacted & $1662 \mathrm{Kg} / \mathrm{m}^{3}$ \\
Natural moisture content \% & 2.3 \\
Absorption \% & 5.3 \\
Silt content \% & 4.0 \\
Grading & Complies with C: BS $882: 1992$ \\
\hline
\end{tabular}


Table 2. Physical properties of marine sand.

\begin{tabular}{cc}
\hline PROPERTY & TEST RESULT \\
\hline Specific gravity SSD & 2.3 \\
Fineness modulus & 0.97 \\
Bulk density; & \\
Loose & $1573 \mathrm{Kg} / \mathrm{m}^{3}$ \\
Compacted & $1746 \mathrm{Kg} / \mathrm{m}^{3}$ \\
Moisture content \% & 3.2 \\
Absorption \% & 13.8 \\
Silt content \% & 2.8 \\
Grading & Close to F, BS 882:1992
\end{tabular}

Table 3. Properties of ordinary Portland cement.

\begin{tabular}{cc}
\hline PROPERTY & TEST RESULT \\
\hline Cement: OPC 42.5 N & \\
Specific gravity & 3.11 \\
Bulk Density: & \\
Loose & $1162 \mathrm{Kg} / \mathrm{m}^{3}$ \\
Compacted & $1398 \mathrm{Kg} / \mathrm{m}^{3}$ \\
Setting time; & \\
Initial setting time & $160 \mathrm{minutes}$ \\
Final setting time & $252 \mathrm{minutes}$ \\
Water demand & $25.65 \%$ \\
\hline
\end{tabular}

Table 4. Chemical analysis of sugarcane bagasse ash.

\begin{tabular}{ccccccccccc}
\hline Parameter & $\mathrm{SiO}_{2}$ & $\mathrm{Al}_{2} \mathrm{O}_{3}$ & $\mathrm{Fe}_{2} \mathrm{O}_{3}$ & $\mathrm{CaO}$ & $\mathrm{MgO}$ & $\mathrm{Na}_{2} \mathrm{O}$ & $\mathrm{K}_{2} \mathrm{O}$ & $\mathrm{TiO}_{2}$ & $\mathrm{MnO}$ & $\mathrm{LOI}$ \\
\hline $\begin{array}{c}\text { Composition } \\
(\%)\end{array}$ & 62.3 & 4.25 & 3.69 & 1.02 & 0.43 & 0.38 & 2.7 & 0.32 & 0.23 & 15.28 \\
\hline
\end{tabular}

Table 5. Mix proportion.

\begin{tabular}{cccccc}
\hline Volume & $\begin{array}{c}\text { SBA } \\
(\mathrm{Kg})\end{array}$ & $\begin{array}{c}\text { Cement } \\
(\mathrm{Kg})\end{array}$ & $\begin{array}{c}\text { Lateritic sand } \\
(\mathrm{Kg})\end{array}$ & $\begin{array}{c}\text { Marine sand } \\
(\mathrm{Kg})\end{array}$ & $\begin{array}{c}\text { Water } \\
(\mathrm{Kg})\end{array}$ \\
\hline $\mathbf{1 . 0 0 \mathrm { m } ^ { 3 }}$ & 35.1 & 198.9 & 856.4 & 367.0 & 117.0 \\
$\mathbf{0 . 3 0 \mathbf { ~ m } ^ { 3 }}$ & 10.5 & 59.7 & 256.9 & 110.1 & 35.1 \\
\hline
\end{tabular}

\subsection{Production and Curing Procedure}

Using the appropriate molds, two types of DHSBs (T-DHSBs and R-DHSBs) were produced. The dimensions for the two types of blocks are shown in Figure 2(a) and Figure 2(b) respectively. 


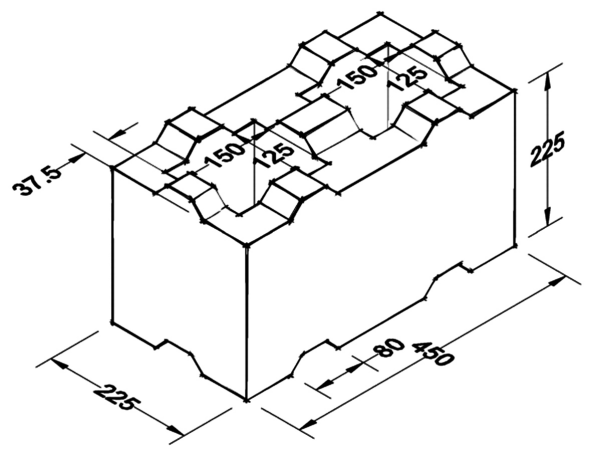

(a)

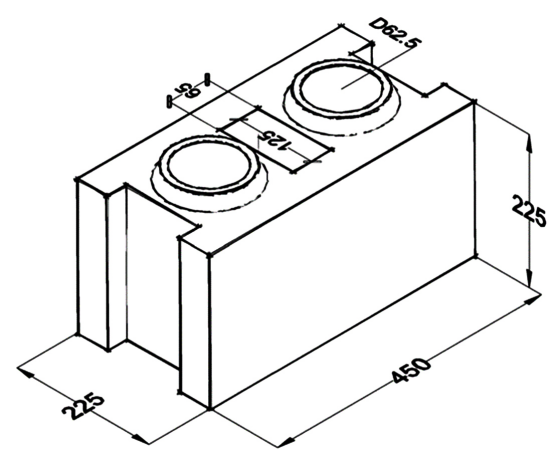

(b)

Figure 2. Drystack hollow sandcrete blocks (Dimensions are in mm). (a) T-DHSB; (b) R-DHSB.

The production procedures involved batching, mixing, casting and compaction. Compaction was done using a wooden rammer. The DHSBs were then allowed to air dry under a shade made with a polythene sheet for 24 hours. Thereafter, curing was done by sprinkling the blocks with water twice a day for one week (see Plate 2). The polythene sheet covering prevented rapid drying out of the DHSBs which could lead to shrinkage cracking [15]. Thereafter, the DHSBs were stacked in rows and columns with a maximum of four DHSBs in a column until they were ready for testing.

\subsection{Experimental Tests and Analysis Procedure}

The compressive tests were conducted after 7, 14 and 28 days of curing. The DHSBs were taken from the stacking area to the laboratory two hours before the test was conducted. This was to normalize the temperature and to make the block relatively dry or free from moisture. The weights of each block were recorded fast before placing the blocks on the compression testing machine. The DHSBs position was such that the top and bottom were molded and lie horizontally on a flat metal plate. The recessions were filled with wooden plates of the exact size to prevent sheaving of the block during testing. The block was then crushed and the corresponding failure load recorded (see Plate 3 ).

The dry density for each testing period was tabulated and the results compared with $1500 \mathrm{~kg} / \mathrm{m}^{3}$ specified by BS 6073-1:1981 [16] recommendation for an average of three (3) blocks and $1600 \mathrm{~kg} / \mathrm{m}^{3}$ recommended by Duggal [17]. The compressive strength was determined by dividing the compression load by the bearing area. The average compressive strength for each age was determined and compared. Graphs showing variations in compressive strength with curing duration were drawn for each type of the dry-stack hollow sandcrete block. The results were compared with the conventional hollow sandcrete block. NIS 87:2000 [15] recommends that the compressive strength of three (3) blocks shall not be less than $3.45 \mathrm{~N} / \mathrm{mm}^{2}$.

The durability of the DHSBs was determined through an abrasion test as described by Raheem et al. [18]. The DHSBs were cured and tested after the 28 


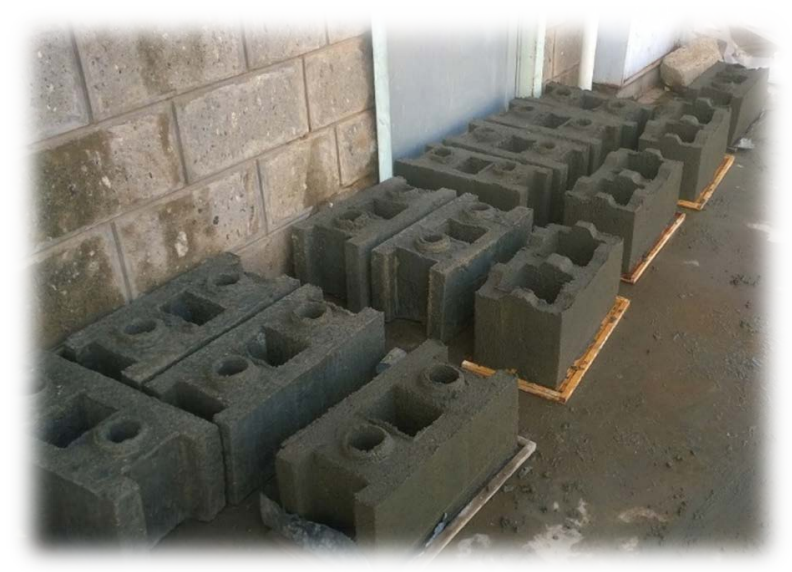

Plate 2. Curing of DHSBs.

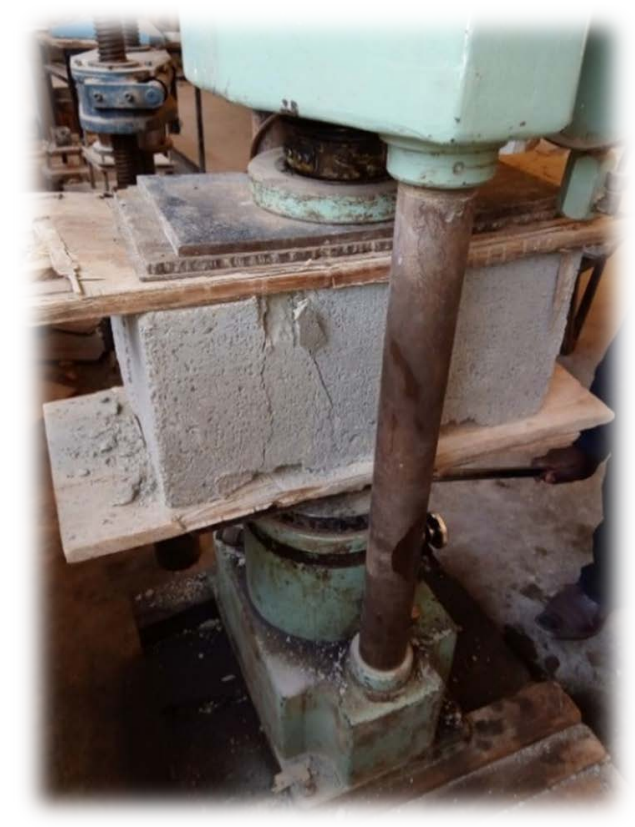

Plate 3. DHSB under compression test.

days. Three DHSBs of each type were selected at random weight recorded. The DHSBs were placed on a smooth and firm surface and then wire-brushed to and fro on all the surfaces 50 times, to and fro making a stroke. After brushing, the DHSBs were weighed again to determine the amount of material of particles abraded. This procedure was repeated for all DHSBs.

In conducting water absorption test, three DHSBs of each batch were selected and oven dried for 24 hours then weighed on a balance of $0.001 \mathrm{~kg}$ accuracy. Thereafter, the DHSBs were then completely immersed in water for 24 hours, after which they were removed and weighed again. The percentages of water absorbed by the DHSBs were estimated using Equation (1) [15].

$$
W_{a}=\left(W_{s}-W_{d}\right) / W_{d}
$$

where: 
$W_{a}=$ Percentage moisture absorption;

$W_{s}=$ Weight of soaked block;

$W_{d}=$ Weight of oven dried block.

The water absorption for the two DHSBs was tabulated and the values were compared with the maximum limit of 12\% recommended by BS 5628-1:2005 [19].

\section{Results and Discussion}

\subsection{Dry Density}

Table 6 shows the dry densities of T-DHSBs and R-DHSBS, determined in accordance with BS 2028:1996 [20]. The average dry densities for T-DHSB were $1659.26 \mathrm{Kg} / \mathrm{m}^{3}, 1656.94 \mathrm{Kg} / \mathrm{m}^{3}$ and $1654.61 \mathrm{Kg} / \mathrm{m}^{3}$ while that of R-DHSB blocks were $1671.90 \mathrm{Kg} / \mathrm{m}^{3}, 1666.27 \mathrm{Kg} / \mathrm{m}^{3}$ and $1662.51 \mathrm{Kg} / \mathrm{m}^{3}$ at 7,14 and 28 days respectively. These values meet the $1500 \mathrm{Kg} / \mathrm{m}^{3}$ BS 2028:1996 [20] recommendation for an average of three blocks as well as the minimum density of 1600 $\mathrm{Kg} / \mathrm{m}^{3}$ recommended by Duggal [17] for load-bearing sandcrete blocks. For all the block types, the individual block's dry density values meet the $1500 \mathrm{Kg} / \mathrm{m}^{3}$ for individual block for a masonry unit as stated in the BS 2028:1996 [20].

Figure 3 compares the densities of the two DHSBs produced in this study with non-dry stacked hollow sandcrete block reported by Arasa et al. [10]. Dry-stack

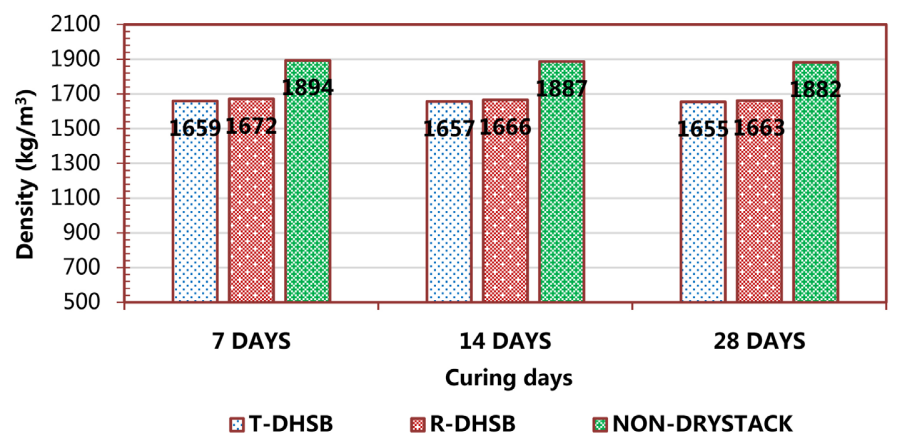

Figure 3. Densities of the T-DHSBs and R-DHSBs.

Table 6. Dry density of dry-stack hollow Sandcrete blocks (DHSBs).

\begin{tabular}{cccccccc}
\hline & & \multicolumn{2}{c}{7 days } & \multicolumn{2}{c}{14 days } & \multicolumn{2}{c}{28 days } \\
\cline { 3 - 8 } $\begin{array}{c}\text { Block } \\
\text { type }\end{array}$ & $\begin{array}{c}\text { Sample } \\
\text { No }\end{array}$ & $\begin{array}{c}\text { Unit } \\
\text { Density } \\
\mathrm{Kg} / \mathrm{m}^{3}\end{array}$ & $\begin{array}{c}\text { Average } \\
\text { Density } \\
\mathrm{Kg} / \mathrm{m}^{3}\end{array}$ & $\begin{array}{c}\text { Unit } \\
\text { Density } \\
\mathrm{Kg} / \mathrm{m}^{3}\end{array}$ & $\begin{array}{c}\text { Average } \\
\text { Density } \\
\mathrm{Kg} / \mathrm{m}^{3}\end{array}$ & $\begin{array}{c}\text { Unit } \\
\text { Density } \\
\mathrm{Kg} / \mathrm{m}^{3}\end{array}$ & $\begin{array}{c}\text { Average } \\
\text { Density } \\
\mathrm{Kg} / \mathrm{m}^{3}\end{array}$ \\
\hline T-DHSB & 1 & 1659.26 & & 1659.26 & & 1659.26 & \\
\hline & 2 & 1659.26 & 1659.26 & 1652.29 & 1656.94 & 1652.29 & 1654.61 \\
& 3 & 1659.26 & & 1659.26 & & 1652.29 & \\
\hline & 1 & 1668.15 & & 1662.51 & & 1662.51 & \\
\hline & 2 & 1673.78 & 1671.90 & 1668.15 & 1666.27 & 1662.51 & 1662.51 \\
& 3 & 1673.78 & & 1668.15 & & 1662.51 & \\
\hline
\end{tabular}


hollow sandcrete block was found to have less density than the non-dry-stack sandcrete blocks. It is also observed that T-DHSBs have a comparatively lower density compared to the R-DHSBs. This difference is attributed to the different void volumes in the blocks. T-DHSBs have a high void volume compared to R-DHSBs hence less dry density. The design of the molds was done in such a manner as to facilitate the manual production of blocks while at the same time achieving approximately a third void volume.

\subsection{Compressive Strength}

The compressive strength of the R-DHSBs and T-DHSBs are presented in Table 7. The average compressive strength for T-DHSBs is $2.17 \mathrm{~N} / \mathrm{mm}^{2}, 2.82 \mathrm{~N} / \mathrm{mm}^{2}$ and $3.58 \mathrm{~N} / \mathrm{mm}^{2}$ while R-DHSBs is $2.24 \mathrm{~N} / \mathrm{mm}^{2}, 2.92 \mathrm{~N} / \mathrm{mm}^{2}$ and $4.04 \mathrm{~N} / \mathrm{mm}^{2}$ at 7, 14 and 28 days respectively. The 28 days strength obtained for both block types exceeds the minimum strength value of $3.45 \mathrm{~N} / \mathrm{mm}^{2}$ specified by NIS 87:2000 [15] for load-bearing walls.

Figure 4 compares the strength of the two types with the non-dry stacked hollow sandcrete block made from the same mix. The results reveal that the non-dry stacked hollow sandcrete blocks made from the same materials show

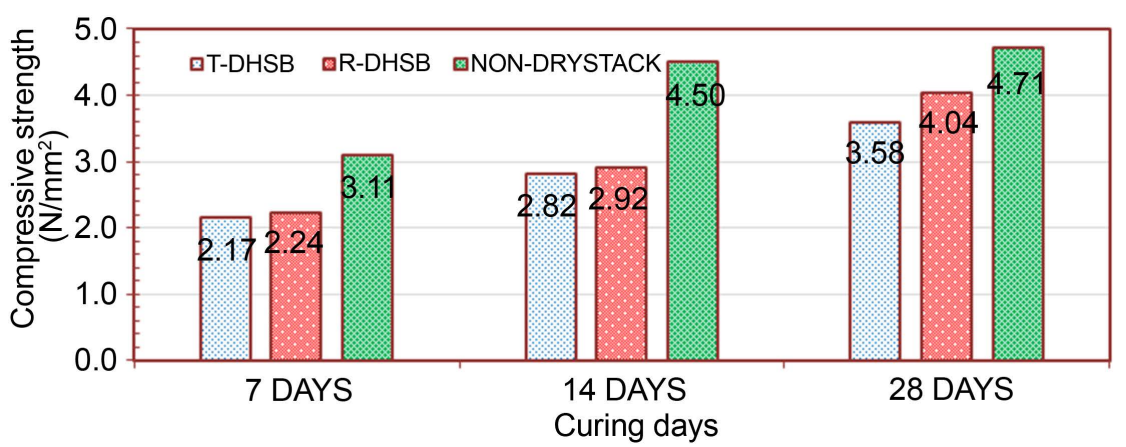

Figure 4. Comparative compressive strength values for DHSBs with non-dry stack hollow sandcrete blocks.

Table 7. Compressive strength of R-DHSBs and T-DHSBs.

\begin{tabular}{|c|c|c|c|c|c|c|c|}
\hline \multirow[b]{2}{*}{$\begin{array}{l}\text { Block } \\
\text { types }\end{array}$} & \multirow[b]{2}{*}{$\begin{array}{c}\text { Sample } \\
\text { No }\end{array}$} & \multicolumn{2}{|c|}{7 days } & \multicolumn{2}{|c|}{14 days } & \multicolumn{2}{|c|}{28 days } \\
\hline & & $\begin{array}{c}\text { Unit } \\
\text { Strength } \\
\mathrm{N} / \mathrm{mm}^{2}\end{array}$ & $\begin{array}{c}\text { Average } \\
\text { strength } \\
\mathrm{N} / \mathrm{mm}^{2}\end{array}$ & $\begin{array}{c}\text { Unit } \\
\text { Strength } \\
\mathrm{N} / \mathrm{mm}^{2}\end{array}$ & $\begin{array}{c}\text { Average } \\
\text { strength } \\
\mathrm{N} / \mathrm{mm}^{2}\end{array}$ & $\begin{array}{c}\text { Unit } \\
\text { Strength } \\
\mathrm{N} / \mathrm{mm}^{2}\end{array}$ & $\begin{array}{c}\text { Average } \\
\text { strength } \\
\mathrm{N} / \mathrm{mm}^{2}\end{array}$ \\
\hline T-I & 1 & 2.20 & & 2.82 & & 3.61 & \\
\hline & 2 & 2.20 & 2.17 & 2.82 & 2.82 & 3.61 & 3.58 \\
\hline & 3 & 2.12 & & 2.82 & & 3.53 & \\
\hline R-DHS & 1 & 2.28 & & 2.92 & & 3.99 & \\
\hline & 2 & 2.28 & 2.24 & 2.92 & 2.92 & 4.06 & 4.04 \\
\hline & 3 & 2.16 & & 2.92 & & 4.06 & \\
\hline
\end{tabular}


comparative higher compressive strength. These varying compressive strength values may be a result shape of blocks, web thickness and cavity size. This also explains why the T-DHSBs have less strength than R-DHSBs.

Ezeokonkwo [21] established that the strength of hollow sandcrete blocks decreases as the cavity volume increases. A greater volume of specimen (solid volume) leads to a more uniform stress distribution and therefore a lesser likelihood of premature failure. The blocks with higher cavities would consequently have comparatively low compressive strength.

\subsection{Water Absorption}

Table 8 presents the results obtained for water absorption at 28 days for the two types of DHSBs. The water absorption for T-DHSBs and R-DHSBs is $8.98 \%$ and 9.39\% respectively. These values are close to those obtained by Anowai and. Afunanya [22] where the highest water absorption rate as $8.25 \%$ for sandcrete blocks contains millet husk ash. The water absorption for block R-DHSB is higher than that of T-DHSB. This may be attributed to increased pores spaces in the blocks due to high volume. Water absorption for both T-DHSBs and R-DHSBs does not exceed the maximum allowed water absorption of $12 \%$ as specified by BS 5628-1:2005 [19]. Nwaigwe et al. [23] explain that poor quality sandcrete block is a result of poor mix ratio, inadequate curing and compaction of the sandcrete blocks. In the event of persistent flooding, a highly porous block could absorb water, consequently become weakened and eventually fail.

\subsection{Abrasion Test}

The Abrasion test results are presented in Table 9.

The percentage of the materials abraded away from the blocks is $0.056 \%$ and $0.051 \%$ for T-DHSBs and R-DHSBs respectively. This implies that there is no significant variation in the durability of the blocks with varying geometrical orientation. The values obtained in this study compare favorably with those of Raheem et al. [18] which recorded a high abrasion value of $0.34 \%$ for laterite

Table 8. Water absorption test result for T-DHSBs and R-DHSBs.

\begin{tabular}{ccccccc}
\hline $\begin{array}{c}\text { Blocks } \\
\text { types }\end{array}$ & S. N & $\begin{array}{c}\text { Weight of } \\
\text { oven dried } \\
\text { block } \\
(\mathrm{Kg})\end{array}$ & $\begin{array}{c}\text { Weight of } \\
\text { soaked } \\
\text { block } \\
(\mathrm{Kg})\end{array}$ & $\begin{array}{c}\text { Weight of } \\
\text { Water } \\
\text { absorbed } \\
(\mathrm{kg})\end{array}$ & $\begin{array}{c}\text { Water } \\
\text { absorption } \\
(\%)\end{array}$ & $\begin{array}{c}\text { Average } \\
\text { water } \\
\text { absorption } \\
(\%)\end{array}$ \\
\hline T-DHSBs & 1 & 23.80 & 26.00 & 2.20 & 9.24 & \\
\hline & 2 & 23.80 & 25.90 & 2.10 & 8.82 & 8.98 \\
\hline & 3 & 23.70 & 25.80 & 2.10 & 8.86 & \\
\hline & 1 & 29.40 & 32.20 & 2.80 & 9.52 & \\
\hline & 2 & 29.50 & 32.20 & 2.70 & 9.15 & 9.39 \\
\hline & 3 & 29.50 & 32.30 & 2.80 & 9.49 & \\
\hline
\end{tabular}


Table 9. Abrasion test results for DHSBs.

\begin{tabular}{ccccccc}
\hline $\begin{array}{c}\text { Blocks } \\
\text { types }\end{array}$ & $\begin{array}{c}\text { Sample } \\
\text { number }\end{array}$ & $\begin{array}{c}\text { Weight } \\
\text { Block } \\
(\mathrm{Kg})\end{array}$ & $\begin{array}{c}\text { Weight } \\
\text { After } \\
\text { Abrasion } \\
(\mathrm{Kg})\end{array}$ & $\begin{array}{c}\text { Weight } \\
\text { abraded } \\
\text { away } \\
(\mathbf{k g})\end{array}$ & $\begin{array}{c}\text { Abrasion } \\
(\%)\end{array}$ & $\begin{array}{c}\text { Average } \\
\text { Abrasion } \\
(\%)\end{array}$ \\
\hline T-DHSBs & 1 & 23.800 & 23.785 & 0.015 & 0.06 & \\
\hline & 2 & 23.700 & 23.690 & 0.010 & 0.04 & 0.056 \\
\hline & 3 & 23.785 & 23.770 & 0.015 & 0.06 & \\
\hline & 1 & 29.400 & 29.385 & 0.015 & 0.05 & \\
\hline & 2 & 29.390 & 29.375 & 0.015 & 0.05 & 0.051 \\
\hline
\end{tabular}

interlocking blocks. The materials abraded away in their study were slightly higher due to the materials used in the study. The lower values obtained in this study ascertained the suitability of the mix to produce durable dry stack hollow sandcrete blocks against abrasive forces.

\section{Conclusions}

The purpose of this study was to investigate the compressive strength and durability performance of DHSBs made from an optimal mix of non-conventional materials. Based on the experimental results and analysis, the following conclusions can be stated:

1) The average 28-day compressive strengths for T-DHSBs and R-DHSBs are $3.58 \mathrm{~N} / \mathrm{mm}^{2}$ and $4.04 \mathrm{~N} / \mathrm{mm}^{2}$ respectively. Thus, the strength of sandcrete block is dependent on the shape of the blocks and cavity volume.

2) The water absorptions of block T-DHSBs and R-DHSBs are $8.98 \%$ and $9.39 \%$ respectively. These values meet the maximum requirement of $12 \%$ specified in BS 5628-1 [19].

3) The materials abraded away from the surface of the two blocks were $0.056 \%$ and $0.051 \%$ for T-DHSBs and R-DHSBs respectively. The minimal percentage is an indication that the blocks are durable under abrasive forces.

4) The optimum ratio of Cement/SCBA to Marine/lateritic of $1(0.85 / 0.15)$ to $6(0.3 / 0.7)$ with water-cement ratio of 0.5 produces DHSBs that meet the compressive strength and durability requirements for hollow sandcrete block.

\section{Acknowledgements}

We are grateful to the Pan African University and Jomo Kenyatta University of Science and Technology for providing the resources and a conducive environment to undertake this study.

\section{Conflicts of Interest}

The authors declare no conflicts of interest. 


\section{References}

[1] Murray, E.B. (2007) Dry Stacked Surface Bonded Masonry-Structural Testing and Evaluation. Master's Thesis, Brigham Young University, Provo.

[2] McKenzie, W.M.C. (2001) Design of Structural Masonry. Palgrave, London.

[3] Jonaitis, B. and Zavalis, R. (2013) Experimental Research of Hollow Concrete Block Masonry Stress Deformations. Procedia Engineering, 57, 473-478.

https://doi.org/10.1016/j.proeng.2013.04.061

[4] Oyebisi, S.O., Afolayan, O.D., Oladeji, S. and Oniemayin, B.I. (2021) Assessing the Low-Cost Buildings in Nigeria Using Hydraform Blocks as Walling Materials: The Journey So Far. IOP Conference Series. Materials Science and Engineering, 1036, Article ID: 012044. https://doi.org/10.1088/1757-899X/1036/1/012044

[5] Ombiro, R.O. and Mbugua, J. (2018) Factors Influencing Use of Interlocking Red Bricks Technology in Housing Projects: A Case of Isiolo County, Kenya. University of Nairobi, Nairobi.

[6] Sornchomkeaw, P. and Duangkeaw, S. (2014) The Study of Compressive Strength of Interlocking Brick by Using Bottom Ash Instead of Cement. American-Eurasian Network for Scientific Information Journals, 9, 12.

[7] Vennila, R., Anuradha, R. and Kavitha, S. (2017) Compressive Strength on Interlocking Concrete Blocks with Acacia Nilotica Ash and Broken Tiles. International Journal of Chem Tech Research, 10, 355-358.

[8] Ahmad, S. (2014) To Study the Behavior of Interlocking of Masonry Units/Blocks. IOSR Journal of Engineering, 4, 39-47.

[9] Assiamah, S., Abeka, H. and Agyeman, S. (2016) Comparative Study of Interlocking and Sandcrete Blocks for Building Walling Systems. International Journal of Research in Engineering and Technology, 5, 1-10.

[10] Arasa, F.O., Onchiri, R. and Abiero-Gariy, Z.C. (2017) Effect of Sugarcane Bagasse Ash on the Engineering Properties of Blended Sandcrete Blocks. International Journal of Engineering Research \& Technology, 6, 327-337.

[11] Kenya Bureau of Standards (2005) KS EAS 18-1: 2001-Cement Part 1: Composition, Specification and Conformity Criteria for Common Cements. Kenya Bureau of Standards, Nairobi.

[12] BSI (1992) BS 882: Specification for Aggregates from Natural Sources for Concrete.

[13] Asiedu, E. and Agbenyega, A. (2014) Suitability of Laterite Fines as a Partial Replacement for Sand in the Production of Sandcrete Bricks Laterite Bricks. International Journal of Emerging Technology and Advanced Engineering, 4, 9-15.

[14] BSI (1980) BS 3148: Methods of Test for Water for Making Concrete.

[15] Standard Organization of Nigeria (2000) NIS 87: Specification for Standard Sandcrete Blocks. Nigeria Industrial Standard.

[16] BSI (1981) BS 6073-1: Precast Concrete Masonry Units. Specification for Precast Concrete Masonry Units.

[17] Duggal, S. (2009) Building Materials. New Age International Publisher, New Delhi.

[18] Raheem, A.A., Falola, O.O. and Adeyeye, K.J. (2012) Production and Testing of Lateritic Interlocking Blocks. Journal of Construction in Developing Countries, 17, 35-50.

[19] BSI (2005) BS 5628-1: Code of Practice for the Use of Masonry. Structural Use of Unreinforced Masonry.

[20] BSI (1996) BS 2028: Specification for Precast Concrete Blocks. British Standard In- 
stitution, Gayland and Sons Ltd., London.

[21] Ezeokonkwo, J.C. (2012) Optimisation of Cavity Size in Hollow Sandcrete Blocks. Journal of Emerging Trends in Engineering and Applied Sciences, 3, 86-90.

[22] Anowai S.I. and Afunanya, J.E. (2017) Millet Husk Ash as Partial Replacement of Cement in Sandcrete Block. International Research Journal of Engineering and Technology, 4, 2-5.

[23] Nwaigwe, D.N., Ogwu, E.A., Ugonna, M.C., Atakpu, O. and Edom, A. (2015) Evaluation of the Quality of Hand Moulded Sandcrete Block in Owerri, Imo State, Nigeria. Journal of Sustainable Development Studies, 8, 252-259. 